\title{
Yosarian Meets "Up the Down Staircase": Teaching the Politics of Crime and Punishment at Penn and in the Pen
}

\author{
Marie Gottschalk, University of Pennsylvania
}

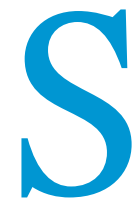

everal weeks into the semester, I arrived for class to discover that six of my students were missing. They had been banished to administrative segregation, also known as solitary confinement or "the hole." In ad seg, they were confined to their cell almost around the clock, with virtually no human contact in conditions that a United Nations special rapporteur characterized as torture for any period lasting more than 15 days. These students were permitted an hour outside their cell each day to shower, make a phone call, watch television alone in a small cage, or exercise in a yard that resembled a small dog run.

Ad seg is said to be reserved for the "worst of the worst" who pose serious threats to safety and security in prisons and jails. However, many of the tens of thousands of people who are housed in solitary confinement on any given day in the United States are there because of prosaic rule violations (e.g., contraband tattoos and piercings). My six students reportedly were sent to "the hole" because they had smoked a joint.

That same semester, one of my best students-a gifted writer and talented artist-was banished to "the hole," allegedly because a correctional officer had a long-standing grudge against him. At the time, Philadelphia's string of jails clustered on the outskirts of the city were grossly overcrowded and understaffed. Here as elsewhere, ad seg was the crude default option to assert authority within chaotic conditions.

These incidents sparked intense classroom discussions about the raw, arbitrary, and unpredictable exercise of power. Once again, the micropolitics of punishment and control bled into the macropolitics of punishment and control, as it had throughout the semester. Again, I wrestled with many unsettling existential, ethical, and pedagogical questions that teaching on the inside raises.

My highest highs and lowest lows as a professor have occurred in courses I taught on the politics of race, crime, and punishment. These include "inside-out classes" held at a maximum-security jail in Philadelphia and composed of Penn students and men incarcerated at the facility, as well as courses taught in a more conventional campus setting. Teaching in a jail or a prison can be exhilarating and deeply satisfying. However, we must be clear-eyed about the unique challenges doing so presents, the potential downsides, and when a timeout might be warranted. Likewise, courses on race, crime, and punishment taught on campus present related and unique challenges.

My best preparation for teaching in Philadelphia's jails was the two years I taught English as a Second Language at a university in the ancient city of Xian just as China was opening up with the dénouement of the Cultural Revolution. A leading authority on correctional health care once told me, "If you have seen one prison, you have seen one prison." The same was true for universities in China when I taught there. Conditions varied enormously among universities even in the same city. They also could change rapidly depending on larger political shifts and how local authorities wielded their considerable discretion in response.

Even within the same jurisdiction, the conditions of confinement can vary sharply among US prisons and jails due to differences in management, shifts in national or local politics, and other factors. When I last taught on the inside a few years ago, the jail was severely overcrowded. This was partly due to the district attorney's new policy to seek sky-high bail amounts in all gun-related cases.

The deteriorating situation behind the walls forced me to question whether the conditions of confinement had become too chaotic, mismanaged, overcrowded, and punitive to teach another semester on the inside. It also spurred me to consider my successes and shortcomings in teaching the politics of crime and punishment in jail and in more conventional classroom settings.

In an authoritarian or semi-authoritarian setting-whether China in the early 1980 os or US jails and prisons todayeducation rests on a precarious foundation. Many US wardens and directors of corrections refuse to permit any inside-out courses and greatly restrict other types of classes and programs that bring civilians into their facilities. Others roll out the welcome mat, but threads of suspicion and ambivalence usually run through it.

Strategic self-censorship is a fact of life when dealing with an authoritarian or semi-authoritarian system. To maintain their access, educators working in US prisons and jails must remain mostly silent about the degrading and dehumanizing 
conditions they routinely witness. They also must weigh their pedagogical commitments to teaching on the inside against their outside research and political commitments to dismanthe the carceral state. The cost of a higher public profile could be banishment from teaching on the inside. inside students about how personal values and individual merit best explain why they ended up in the Ivy League.

Some inside students demonstrated a highly nuanced understanding of the interplay of individual and structural factors to explain why they ended up in jail. For some, nar-

\section{In an authoritarian or semi-authoritarian setting-whether China in the early 1980 os or US jails and prisons today-education rests on a precarious foundation.}

Teaching behind the walls entails embracing unpredictability and accepting a loss of control. You arrive at the jail one week to discover class is canceled because the facility just went on lockdown. The next week, you find that your inside students no longer have their course materials. During the lockdown the previous week, correctional officers threw them into the trash when they "tossed" cells looking for contraband. Navigating to get those materials to the incarcerated students when the semester began weeks earlier no longer seemed a victory-in a way that Yosarian in Joseph Heller's Catch-22 would have appreciated.

As I learned in China, authoritarian and semi-authoritarian systems run on discretion and indirection. While waiting to clear security, a correctional officer declared that the sweater a Penn student was wearing violated the facility's dress code. The student's polite entreaties that she had worn the sweater into the jail several times without a problem were futile. They also backfired. Directly challenged, the correctional officer used his enormous discretion to warn that other students waiting behind her in line might also be in violation of the dress code.

I tried to recruit a diverse group of Penn students. However, in the early years of teaching this course, most of my Penn students were white women. My inside students were drawn from a maximum-security jail for men, $90 \%$ of whom were black. This image reinforced troubling stereotypes.

In selecting Penn students, I attempted to screen out voyeurs or those who simply were looking for a "leg up" on law-school applications or to make small talk at weekend parties. However, some slipped through despite my attempts.

Some Penn students had trouble stepping outside of their bubble. As we were clearing the security line one time after spring break, several students were comparing notes about their trips to Costa Rica, Mexico, and Florida. They appeared oblivious to the correctional officer rolling his eyes and to the pains of imprisonment that coursed through the jail's dilapidated and overcrowded waiting room as friends and family members waited to visit loved ones on the inside.

The structural, institutional, and political factors that explain why the United States is the "world's warden" are a major theme of my courses. As the semester unfolds, the inside and outside students sharpen their understanding of how these factors are critical in determining who lands up at Penn and who lands up in the pen. However, individualistic, meritocratic explanations continued to stalk my courses like zombies refusing to die. Several times I heard Penn students lecturing ratives of personal responsibility were an invaluable resource for the transformation needed to propel them to desist from crime and stay out of prison.

However, the focus on structural, institutional, and political factors also can foster cognitive dissonance. Most of my inside students were enrolled in substance-abuse or rehabilitative programs that emphasize how the key to successful reentry and desisting from crime depends on "fixing" their individual shortcomings. This meant recognizing their "bad choices" and avoiding the people, places, and things that prompted them. It also entailed participating in a whirlwind of programs designed to fix their individual deficitsanger-management, parenting, GED, and resume-writing classes.

Local social, political, and economic conditions are critical factors in determining who ends up on a path out of the criminal-justice system and who ricochets back into it. Just don't tell all of this to the judge. Mentioning the "prison beyond the prison," the gross inequities of the carceral state, and how an increasingly punitive political climate contributed to an unprecedented rise in incarceration rates can be interpreted as acts of denial about one's own bad choices. It certainly does not bolster your case with judges, social workers, and psychologists charged with determining who should be released sooner rather than later.

A single-minded embrace of deeper structural factors can have other costs. As numerous psychological studies have shown, believing you have a sense of efficacy and control over your fate can be critical for personal happiness.

Advocates of inside-out and other prison-education programs tend to promote the rhetoric of recidivism reduction. It is the main wedge for educators to "get their foot in the door" of the local prison or jail. However, this also is a dodgewhether or not a conscious one-that deflects attention from the fact that education can be a fundamentally subversive act.

The very existence of a classroom inside a prison or jail where incarcerated people are treated as students-not as inmates and criminals-is subversive. In his autobiography, Malcolm Little credited his studies at Norfolk Prison and the facility's outstanding library with his transformation from street hustler to the man later known as Malcolm X.

The study of politics is primarily a study of powerdetermining who gets what and why. Like the best political science classes on the outside, teaching the politics of crime and punishment on the inside demands an analysis of the conventional wisdom about why the United States is the 
world's warden. It also entails engaging with the micropolitics of the semi-authoritarian or authoritarian system that rules the lives of inside students $24 / 7$. An interrogation of the carceral state also entails a wider interrogation of the health of democratic institutions in the United States and the role and practices that diffuse to other groups in the United States. African Americans are much more likely than whites to be swept up in the war on drugs. Yet, the racial gap has been narrowing. As the war on drugs winds down on some fronts, it has intensified elsewhere-notably in rural, predominantly

\section{Mentioning the "prison beyond the prison," the gross inequities of the carceral state, and how an increasingly punitive political climate contributed to an unprecedented rise in incarceration rates can be interpreted as acts of denial about one's own bad choices. It certainly does not bolster your case with judges, social workers, and psychologists charged with determining who should be released sooner rather than later.}

and purpose of education more broadly. Professors, deans, and college presidents routinely intone the mantra that learning how to think critically is a key goal of education. In classrooms on both sides of the prison gates, however, the capacity for critical thinking is under assault.

"Successful" reentry-for people released from prison and for students graduating from college and entering the job market-has become the leading justification for investing in education. Programs that cannot demonstrate their worth-as evidenced by lower recidivism rates for those released from prison and higher salaries for college graduates-are deemed less worthy or even irrelevant. Across the country, college and university administrators are eliminating majors in the humanities and social sciences as they seek to put their STEM programs on steroids. Penn students enrolled in my inside-out classes have reported a parent complaining that "I don't pay $\$ 70,000$ a year to send you to prison each week."

In any course on crime and punishment, assessing the role of racial factors is extremely challenging. Most students begin the semester wedded to at least one of the following suppositions: (1) rising crime rates are the primary driver of escalating incarceration rates; (2) mass incarceration significantly reduces crime rates; and (3) mass incarceration is the "new Jim Crow." Over the course of the semester, most students come to appreciate that whereas rising crime rates may have been a proximate cause of mass incarceration, a complex interplay of social, racial, political, institutional, and economic factors is the underlying cause. Likewise, they generally accept the findings of the National Academy of Sciences that mass incarceration had at most only a very modest impact on reducing crime rates. Convincing them to see the limitations of the "new Jim Crow" framework is the greatest challenge.

Michelle Alexander and others presented convincing evidence that racial animus and the quest to preserve white supremacy are central factors in the prison boom. The popularity of Alexander's account of the new Jim Crow and Ava DuVernay's film 13th reinforced a tendency to view mass incarceration and the carceral state primarily through a racial-disparities lens that focuses almost exclusively on its impact on black men and their families and communities.

However, as the racial order continues to invent new ways to target African Americans, it has generated punitive policies white areas that reportedly are experiencing methamphetamine and opioid epidemics. Capturing and detaining immigrants has become one of the most dynamic growth areas of the carceral state. Whites are more likely to be involved in the war on those accused of sex offenses, which has been gaining momentum since the 1990s and eerily parallels the war on drugs. In short, the United States would still have an incarceration crisis even if it were locking up African Americans and Latinos "only" at the rate at which whites are currently incarcerated-or if it were not locking up any African Americans and Latinos.

Teaching about crime and punishment in a conventional classroom setting has its own special challenges. Attending class each week in a maximum-security jail alongside people accused of crimes dissolves widespread stereotypes about "criminals," their innate wickedness, and the punishments they deserve. In conventional classes on the outside, this is more difficult. In all of my courses on crime and punishment, I assign poems, short stories, and essays written by people who have been incarcerated. This includes works by renowned authors, such as Malcolm X and George Jackson, and those lesser known, such as Jarvis Jay Masters, who is on death row in San Quentin. His essay, "Mourning Exercise," seldom leaves a dry eye when read in the classroom.

I also invite formerly incarcerated people to speak to my conventional classes on the Penn campus. In recognition of their time, experience, and expertise, I give them a modest honorarium. These returning citizens are extremely knowledgeable about the politics of criminal justice; many have earned a BA or an associate's degree from Villanova University, which has been running a degree-granting program for decades at Pennsylvania's largest prison.

Pennsylvania's dubious distinction of having the largest population of juvenile lifers in the country-indeed, in the world-has become an asset for teaching purposes. With the US Supreme Court's three recent landmark cases declaring that mandatory life sentences for juveniles are unconstitutional, dozens have been released in Pennsylvania. They have become an important resource for educating students, policy makers, and the general public about penal policy. They were a force to be reckoned with in the upset victory of insurgent Larry Krasner in the 2017 district attorney's race in Philadelphia. 
A "tour" of the local prison or jail is another way to break down stereotypes and misunderstandings about people who are incarcerated. However, this is fraught with ethical dilemmas. ${ }^{1}$ For many years, the head of public relations for the Philadelphia jails welcomed meetings with a group of incarcerated men or women as a routine part of a tour of the facility. treated as interchangeable and synonymous. Communityservice programs have the virtue of appearing "apolitical." They can reduce calls for other types of community engagement, such as pressuring universities to agree to PILOTS (i.e., payments in lieu of taxes) to support underfunded urban school districts.

\section{Most students begin the semester wedded to at least one of the following suppositions: (1) rising crime rates are the primary driver of escalating incarceration rates; (2) mass incarceration significantly reduces crime rates; and (3) mass incarceration is the "new Jim Crow."}

Since he retired, arranged visits to Philadelphia's largest jail no longer include such meetings. Visits feel more like a trip to the zoo and a gross violation of the rights and dignity of the people incarcerated at the jail. My last class visit to a Philadelphia jail a few years ago was a highly orchestrated event akin to visiting a Potemkin village. It left me so uncomfortable that I have not arranged a return visit.

Fortunately, administrators at Graterford state prison near Philadelphia were relatively more open compared to corrections administrators at other penal facilities. I tried each semester to arrange a discussion about criminal-justice reform with my class and members of Graterford's lifers' association. When I did succeed in getting permission, the evening visit to Graterford was always a highlight of the semester for students. With the recent closure of Graterford and the opening of its \$400 million replacement in July 2018, it remains unclear whether such visits will resume.

After learning about the carceral state, many inside and outside students wrestle with the question, "What's next?" For many Penn students-even political science majors-the default option is to channel their concerns into community service rather than political activism. This has become less surprising and more comprehensible to me. Penn and many other colleges and universities currently support a major investment in community service through numerous voluntary programs and organizations. In doing so, they foster a culture in which community service and community engagement are
For many students, today's problems-climate change, unprecedented economic inequality, the carceral state-seem intractable. Community service-such as tutoring at a local school or volunteering at a food bank-provides an immediate sense of efficacy and satisfaction in the face of such overwhelming problems. However, as prize-winning prison poet Diane Hamill Metzger implores:

Don't make me your project; instead,

Join me in my screams for freedom,

So I can walk my life

On my own unassisted legs.

Some inside and outside students are choosing a more political path. They have mobilized to ban the box on The Common Application, to end cash bail by establishing bail funds and court-watcher programs, and to campaign for a new type of district attorney. In short, they are joining in the screams for freedom.

\section{NOTE}

1. For an excellent survey of these dilemmas from the point of view of an incarcerated person, see Minogue 2003.

\section{REFERENCE}

Minogue, Craig W. J. 2003. "Human Rights and Life as an Attraction in a Correctional Theme Park." Journal of Prisoners on Prisons 12: 44-57. 


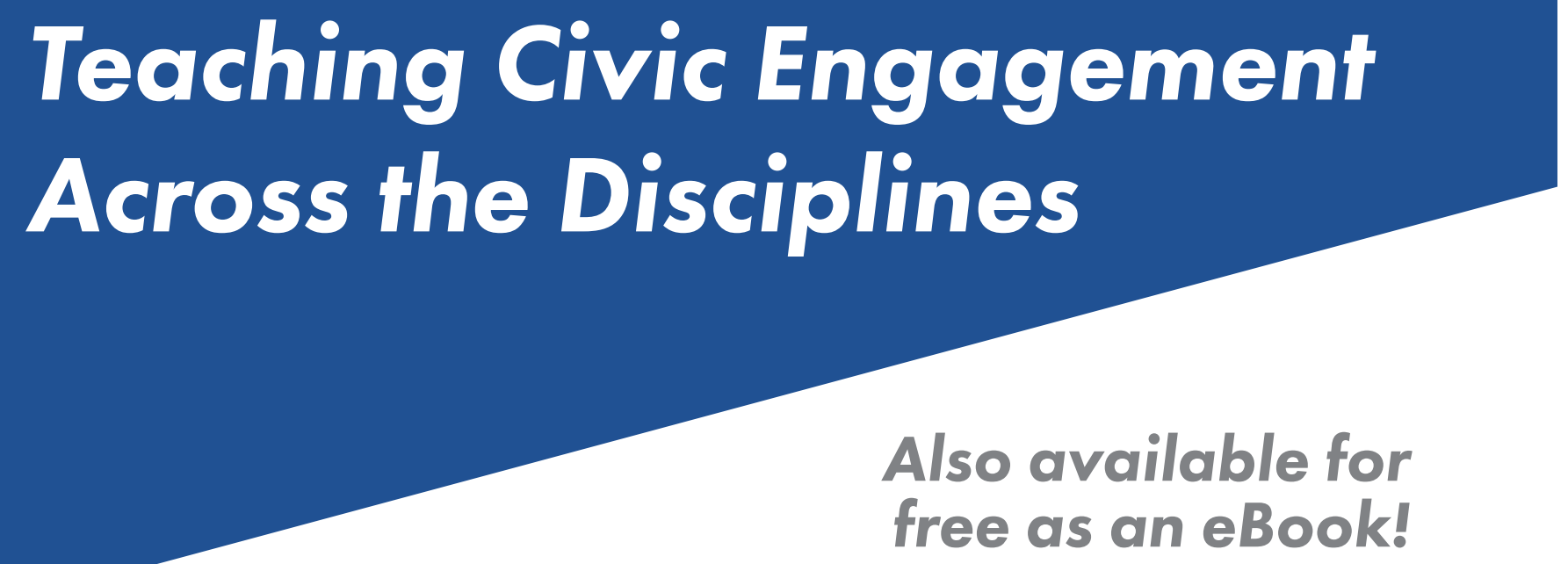

A new wave of civic instruction is moving through American education. As numerous national groups and institutions are joining this effort, political science is uniquely equipped to advance the teaching of civic engagement. The discipline should lead the movement for high quality civic education across the curriculum and across the disciplines.

To focus on this wave of civic engagement education, APSA is publishing the book Teaching Civic Engagement Across the Disciplines, edited by Elizabeth C. Matto, Rutgers University; Alison Rios Millett McCartney, Towson University; Elizabeth A. Bennion, Indiana University; and Dick Simpson, University of Illinois at Chicago.

The book redirects the focus from teaching better political science courses to teaching civic engagement across the disciplines. This movement involves university-wide coordinated civic engagement programs and action plans as well as a new nationwide action plan across high schools, community colleges, four-year colleges, and research universities to consolidate the gains that have been made and provide resources for the next leap forward. Building on the 2013 book Teaching Civic Engagement: From Student to Active Citizen, this book advances the conversation on civic engagement and provides critical scholarly insight into where to go next.

Available for purchase on Amazon! Visit www.apsanet.org/tce2.

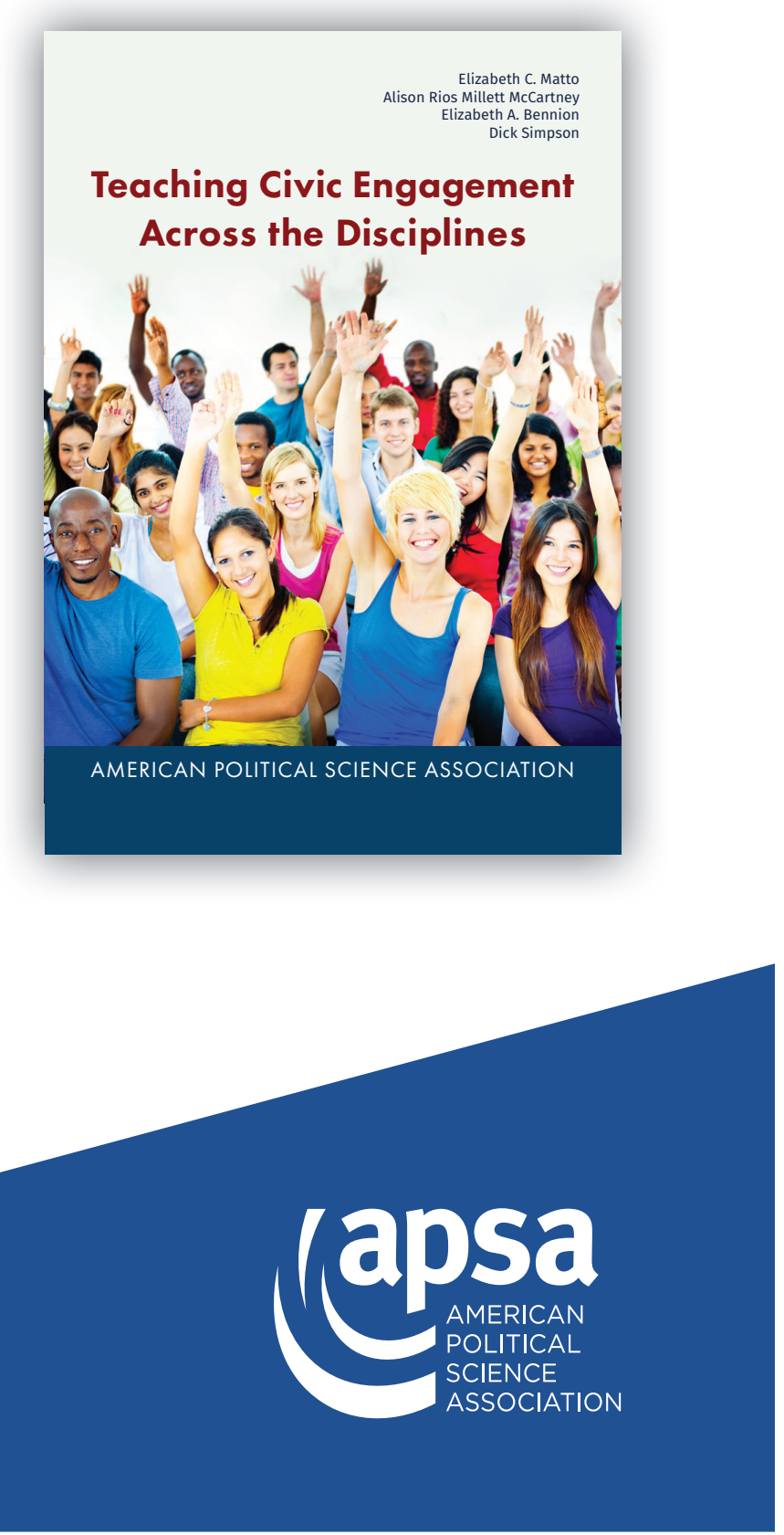

